\title{
Bottom-up Urban Regeneration and Vacant Buildings: A Framework to understand how Empty Properties can be Strategically Embedded in Bottom-up Projects
}

\begin{abstract}
By Alberto Squizzato*
The bottom-up projects, in the years after the Great Crisis, have been considered as a popular measure to solve urban issues, overcoming the conditions of austerity faced by public actors. However, these initiatives not only seem confined to solve very specific issues but are often linked to a more comprehensive urban regeneration strategy, thus capable of addressing the economic, social and physical aspects of a wider part of the city. This article presents the first findings of wider research, which analyses the link between bottom-up practices and the concept of urban regeneration. In particular, this article focuses on an element that appears to be fundamental for the development of these bottom-up urban regeneration practices: the presence of vacant buildings available for the reuse. This article suggests the possibility to analyse how vacant buildings are embedded in these practices through three steps, called steps for the regeneration through the reuse of vacant buildings (SteRVs), namely Recognition, Appropriation and Design. The validity of the three phases is demonstrated through a multiple case study analysis, that considers two renowned bottom-up urban regeneration cases developed in Europe mainly after 2000: Farm Cultural Park, in Favara (Italy) and NDSM wharf, in Amsterdam.
\end{abstract}

\section{Introduction}

Urban regeneration, according to the widely accepted definition provided by Roberts, ${ }^{1}$ is the 'comprehensive and integrated vision and action which seeks to resolve urban problems and bring out a lasting improvement in the economic, physical, social and environmental condition of an area that has been subject to change or offers opportunities for improvement'. However, in the contemporary debate, the term appears to be used in a wider and less precise way, including 'a lot of various interventions in the city related to urban design and planning, social and economic renewal or cultural planning "regeneration.",2

In the current debate the concept of 'urban regeneration', used with its wider meaning, is often related to practices that are developed 'from the bottom-up'. The main characteristic of 'bottom-up' practices is to involve the dimension of the

${ }^{*} \mathrm{PhD}$ Candidate, Université Libre de Bruxelles, Belgium.

1. P. W. Roberts, "The Evolution, Definition and Purpose of Urban Regeneration," in Urban Regeneration, 9-43. (eds.) P. W. Roberts, H. Sykes and R. Granger. $2^{\text {nd }}$ Edition. Los Angeles: Sage, $2017,18$.

2. A. Acierno, "Integrated Urban Development and Culture-Led Regeneration in the EU," Territory of Research on Settlements and Environment. International Journal of Urban Planning 10, no. 1 (2017): 7. 
social responsibility, meaning that the objective is not the individual profit but instead a redistribution of benefits. ${ }^{3}$ The bottom-up projects largely base on the strong participation of people, also on a voluntary basis. ${ }^{4}$ This tendency is shown in a large number of projects developed since 2000, in the period defined as 'regeneration in recession.

Even though the definition of urban regeneration is currently used in a wider and less precise way, it still refers to a practice developed in order to improve neglected or deprived urban areas. Regarding the physical aspects, urban regeneration is developed in contexts of degraded urban fabrics, where it is possible to find a large number of buildings in poor conditions and often a certain presence of vacant estates. The market value of the estates is often an indicator of the issues faced by an urban area, indicating the lack of appeal of the existing buildings. The presence of an extraordinarily high rate of vacant buildings can indicate the need for an urban regeneration project to be implemented. As a matter of fact, regeneration strategies and the presence of vacant buildings are often combined in bottom-up urban projects.

Vacant buildings seem to be both a reason and an opportunity for the bottomup projects to grow. The research project 'Urban Catalyst', which produced a large debate on temporary uses and that contributed to acknowledge the importance of the 'do-it-yourself' approach to urban planning, recognized the importance for informal practices to find space 'available at a reasonable cost or even at no charge. ${ }^{6}$ Such projects, where 'Individual initiative, sociocultural capital, and the principle of minimum intervention take the place of financial means, ${ }^{7}$ often face issues connected to the financial sustainability, having troubles in sustaining current expenditures. This translates in the necessity to base their activities in buildings remained vacant, available at no or low charge.

However, there is little literature about how the vacant buildings are strategically integrated into bottom-up initiatives that are supposed to achieve the urban regeneration of deprived areas. In this article the role played by the presence of vacant buildings is analysed, and it appears as an element not only common to a countless number of bottom-up projects, but also one of the premises that permit these initiatives to begin and develop. The methodology used is the multiple case studies, in consideration of its capacity to analyse a contemporary phenomenon in its real context, ${ }^{8}$ combining literature review (theoretical framework), desktop research (secondary sources) and qualitative methods (interviews), comparing two European projects developed mainly after 2000, during the period of the

3. C. Rabbiosi, "Urban Regeneration "from the Bottom up": Critique or Co-Optation? Notes from Milan, Italy," City 20, no. 6 (2016): 832-844.

4. F. Tonkiss, "From Austerity to Audacity: Make-Shift Urbanism and the Post-Crisis City," in Make_shift City: Renegotiating the Urban Commons; Die Neuverhandlung Des Urbanen, 165167 (eds.) F. Ferguson and Urban Drift Projects. Berlin: Jovis, 2014.

5. Roberts, "The Evolution, Definition and Purpose of Urban Regeneration," 2017.

6. P. Oswalt, K. Overmeyer and P. Misselwitz (eds.) Urban Catalyst: The Power of Temporary Use (Berlin: DOM Publishers, 2013), 14.

7. Ibid.

8. R. K. Yin, Case Study Research: Design and Methods (Thousand Oaks: Sage Publications, 1994). 
'regeneration in recession.' Through this methodology, three steps for the regeneration of the vacant buildings are individuated and their consistency with the actual development of the projects is demonstrated.

The paper is developed in more four sections: the second demonstrates the theoretical possibility of the existence of bottom-up urban regeneration, the third analyses relevant literature on vacant buildings, in the fourth the research question and the three steps for the reuse of the vacant buildings (SteRVs) are presented, in the fifth the two case studies are analysed. Finally, the conclusions will be presented.

\section{Around the Existence of Bottom-up Urban Regeneration}

The cause-effect link between the bottom-up activities and the concept of urban regeneration, as defined in academic literature is not yet fully demonstrated, ${ }^{10}$ but it is currently a subject of doctoral research. ${ }^{11}$ However, the existence of a link between the reuse of a building and the regeneration of a wider area is grounded on at least three theoretical elements.

First, its existence is confirmed by a general conviction of academics and urban practitioners. As Julie Fanovard ${ }^{12}$ states, the projects of occupation, even if temporary, 'are an added value for the occupier, but also for the society itself', benefitting the surrounding neighbourhood through the opening of new activities like 'bike workshop open to all residents of the neighbourhood, a grocery store, a homework school ... ${ }^{13}$ Furthermore, as demonstrated in a previous article, in at least two European experiences, namely NDSM wharf in Amsterdam and FARM Cultural Park in Favara (Italy), bottom-up activities and urban regeneration appear to be consequential, basing on the promoters' opinions. ${ }^{14}$

Second, many authors admit the existence of catalysts in the urban environment: Attoe and Logan ${ }^{15}$ admit the possibility of an urban 'catalytic effect', defined as the possibility given by 'the introduction of a new element (the catalyst)' to cause 'a reaction that modifies existing elements in the area', that led

9. Roberts, "The Evolution, Definition and Purpose of Urban Regeneration," (2017).

10. A. Squizzato, "Understanding and Evaluating Bottom-up Urban Regeneration," in Urbanism Research across the World: Proceedings of the PHD Seminar, $34-39$ (eds.) K. Shannon and M. Quang Nguyen. Leuven: KU Leuven Department of Architecture, 2019.

11. Squizzato, "Urban Regeneration: Understanding and Evaluating Bottom-up Projects," Urbanities 9, no. 2 (2019): 19-35.

12. J. Fanovard, Convention d'occupation précaire et temporaire à Bruxelles. Une solution à la crise du logement? (Bruxelles: CPCP, 2017), 14.

13. 'Ces projets sont une plus-value pour l'occupant, mais également pour la société ellemême. Au-delà de la vie collective qui se met en place au sein du bâtiment, certains projets s'ouvrent également sur le quartier : atelier vélo ouvert à tous les habitants du quartier, une épicerie, une école des devoirs...' 2019.

14. Squizzato, "Urban Regeneration: Understanding and Evaluating Bottom-up Projects,"

15. W. Attoe and D. Logan, American Urban Architecture: Catalysts in the Design of Cities (Berkeley: University of California Press, 1989). 
to a product that is better than the sum of its ingredients. ${ }^{16}$ Moreover, the research 'Urban Catalyst' confirmed how 'spontaneous, temporary uses have positive longterm effects, both at the sites where they were originally located and well beyond. ${ }^{17}$

Third, the phenomenon called 'Bilbao-effect', defined as the possibility for a single architectural intervention to generate effects on a wider scale, even if questioned in its long-term outcomes seems to still have validity. ${ }^{18}$

The link between bottom-up practices and urban regeneration, if not yet proven, can be, however, considered based on a large academic consensus. Admitting the existence of this link, the following sections will present how this relation involves also the reuse of vacant buildings, which can become an important asset for the development of these practices.

\section{The Vacant Buildings: Problem or Occasion?}

Many factors can produce the phenomenon of vacant buildings. It can descend from the specific conditions of a building, or macro trends that can influence the whole real estate market of an area. Depopulation and migrations, deindustrialisation or economic development are dynamics that change the pressure on the real estate sector, requiring the construction of buildings, or on the opposite generating loss of value and abandonment of urban areas. ${ }^{19}$ This article will not delve deeper in the causes that generate a vacant property, that differ for each case, and whose macro trends are broadly discussed in the literature. ${ }^{20}$ This paper will instead consider the presence of a vacant building as an existing premise, an element whose existence is given.

Academics suggest the impelling need for public administrations to push for the reduction of vacant properties, in order to contain the land and energy consumption, ${ }^{21}$ to control the crime ${ }^{22}$ and reduce the costs. ${ }^{23}$ Wilkinson's definition

16. Attoe and Logan, American Urban Architecture: Catalysts in the Design of Cities, $1989,46-47$.

17. Oswalt, Misselwitz and K. Overmeyer, "Patterns of the Unplanned," in Loose Space: Possibility and Diversity in Urban Life, 271-288 (eds.) K. A. Franck and Q. Stevens. London; New York: Routledge, 2006, 280.

18. A. Franklin, "Journeys to the Guggenheim Museum Bilbao: Towards a Revised Bilbao Effect," Annals of Tourism Research 59 (2016): 79-92.

19. B. Manganelli, Real Estate Investing (Cham: Springer International Publishing, 2015).

20. S. Alker, V. Joy, P. Roberts and N. Smith, "The Definition of Brownfield," Journal of Environmental Planning and Management 43, no. 1 (2000): 49-69; A. Mallach, A. Haase and K. Hattori, "The Shrinking City in Comparative Perspective: Contrasting Dynamics and Responses to Urban Shrinkage," Cities 69 (2017): 102-108; P. Marcuse, "Gentrification, Abandonment, and Displacement: Connections, Causes, and Policy Responses in New York City," Washington University Journal of Urban and Contemporary Law 28 (1985): 195-240.

21. D. Myers and P. Wyatt, "Rethinking Urban Capacity: Identifying and Appraising Vacant Buildings," Building Research \& Information 32, no. 4 (2004): 285-292.

22. W. Spelman, “Abandoned Buildings: Magnets for Crime?" Journal of Criminal Justice 21, no. 5 (1993): 481-495. 
of vacant buildings underlines the issue they represent: 'Vacant properties can be defined as any residential, commercial, or industrial buildings or lots that pose a threat to public safety and thus meet the definition of a public nuisance. ${ }^{24}$ Furthermore, Wilkinson sustains that they are 'detrimental to cities and burden communities in a myriad of ways. ${ }^{25}$

If the reduction of abandoned buildings is a need for public authorities, the solutions adopted are different. The potential approaches involve subsidizing the extra costs faced by the community, developing policies that favour the intervention on existing buildings, or intervening actively through public development agencies. However, not all the public administrations are willing nor have the funds necessary to directly intervene in solving the issue of an abandoned building in their territory.

For these reasons, it appears relevant to analyse and compare different paths that vacant buildings may follow in order to be reactivated and reused directly by citizens, in the context of bottom-up projects. This work is based on the hypothesis that understanding how vacant buildings have been embedded in past successful bottom-up UR projects would help future strategies of public administrations, professionals, urban practitioners, academics and citizens. The research question to which this work attempts to answer is: how have vacant buildings been embedded in successful cases of bottom-up urban regeneration in Europe?

Despite the importance of the topic, a few works studied the link between the reuse of empty estates and urban regeneration strategies.

Many different actors demonstrated interest in this topic in recent years. It will be useful to briefly recall some works and experiences, also to demonstrate the necessity and opportunity to further contribute to this research field.

The importance of vacant buildings is confirmed by the existence of selfconstituted networks of citizens that aim at giving new meaning and bring new activities inside the cities.

It is the case of Trans Europe Halles (TEH), a network born in 1983 in Brussels with the scope of giving a unique representation to the European bottomup cultural centres. ${ }^{26}$ In fact, as Sayin, the communication manager of the network, pointed out in a recent interview, ${ }^{27}$ solving the issue of vacant buildings was the main concern that conducted to the foundation of the network: 'there are so many empty industrial buildings that are abandoned, unused, empty around Europe at the moment, how can we reuse these buildings and spaces for culture and art? ${ }^{28}$ This initial intention is still a prerequisite in order to become a member of TEH,

23. B. Winthrop and R. Herr, "Determining the Co\$t of Vacancies in Baltimore," Government Finance Review 25, no. 3 (2009): 38-42.

24. L. Wilkinson, "Vacant Property: Strategies for Redevelopment in the Contemporary City" (2011): 2.

25. Ibid.

26. B. Sayin, Personal Interview, 2019.

27. Ibid.

28. Ibid. 
which accepts only 'citizen-initiated', 'independent and not-for-profit' cultural centres 'based in a repurposed building." 29

Also, the Italian based ReCreo (recreo.network) was born on similar concerns. ReCreo attempts to build a map of rural vacant buildings in Italy, in order to connect the owners and citizens that have a proposal for the reuse. ${ }^{30} \mathrm{ReCreo}$ is essentially a web-based platform, where citizens can collaborate in building a map that individuates the presence of all the vacant estates, considering the buildings but not only. Moreover, people that have an idea for the spaces can register the platform to communicate their ideas, making possible a positive encounter between the owner and any actors that need a space.

Outside Europe, this interest is also present. To mention the work of the NGO 'Center for Community Progress' (United States) which defines itself 'the only national nonprofit specifically dedicated to building a future in which vacant, abandoned, and deteriorated properties no longer exist'. Center for Community Progress, in particular, dedicated great effort in understanding the relationship between vacant buildings and possible bottom-up initiatives, in the framework of the so-called 'creative placemaking'. The report 'Creative Placemaking on Vacant Properties: Lessons Learned from Four Cities' represents a significant contribution in the field, recognising the importance of citizen-initiated activities in the sector of art and culture in triggering positive economic development, social and cultural positive impacts. ${ }^{31}$ However, the Center for Community Progress advocates for more general solutions to the problem, ${ }^{32}$ focusing on large scale approach, and seems less interested in understanding the ways through which it is possible to achieve the reuse of a single building, which is instead the central topic of this article.

These are only three examples of how the presence of vacant buildings strikes the citizens' imagination and triggers creative projects and networks.

The reuse of empty buildings in contemporary cities has been recognized as an opportunity also by public actors. The recent activities carried by a network of eleven cities in the framework of European programme $\mathrm{URBACT}^{33}$ aimed at working on the concept of reuse, to 'support a sustainable city and neighborhood development'. This network, called $2^{\text {nd }}$ Chance, has developed a guidebook for the reuse of vacant industrial buildings. Adopting the public administration's point of

29. Trans Europe Halles, "How to Become a Member." Trans Europe Halles (2019). Retrieved from: http://teh.net/members/.

30. L. Porcelloni, L. Cusseau, S. Amini and F. Mazzelli, “Abbandono Di Aree Rurali e Reti Innovative Di Rigenerazione: Una Proposta Di Nuovi Modelli Dell'Abitare Attraverso Una Mappatura Condivisa," in Territori Spezzati. Spopolamento e Abbandono Nelle Aree Interne Dell'Italia Contemporanea, 149-154 (eds.) G. Macchi Jánica and A. Palumbo. Roma, CISGE Centro Italiano per gli Studi Storico-Geografici, 2019.

31. Metris Arts Consulting, and Center for Community Progress, Creative Placemaking on Vacant Properties: Lessons Learned from Four Cities (Center for Community Progress, 2018).

32. J. R. Leonard and A. Mallach, Restoring Properties, Rebuilding Communities. Trasforming Vacant Properties in Today's America (Center for Community Progress, 2010).

33. N. Scheffler, Waking up the Sleeping Giants. An Urban Guidebook for the Reactivation and Reuse of Larger Vacant Buildings (URBACT, 2018). 
view, the guidebook, edited by the lead expert Sheffler, individuated six key activities that are necessary in order to achieve full reuse of the vacant buildings: ${ }^{34}$

- understanding the current state of the building and its history;

- making stakeholders and citizens aware of the building;

- opening the building;

- engaging stakeholders in the reactivation process;

- developing a reactivation strategy embedded in the city development strategy;

- checking for alternative financial resources.

Differently from the above-presented experiences, the intention of this article is not to produce any directly operative knowledge but instead to develop a conceptual framework that will be useful in further works.

\section{Three Steps for the Regeneration through the Reuse of Vacant Buildings (SteRVs)}

The process through which a vacant building becomes an asset in a UR project is complex and differs in each case. However, the article demonstrates the possibility to distinguish at least three phases, each characterized by its proper goals and outcomes, through which the empty buildings can become part of a more comprehensive UR strategy.

In order to develop this theoretical framework, different analyses on the selected projects have been conducted:

- $\quad$ the review of the interventions, basing on the secondary sources collected for each case study;

- $\quad$ interviews with relevant actors, in order to have a deeper understanding of the overall development and the various initiatives;

- the listing the activities, distinguishing between physical and nonphysical interventions;

- the categorisation of the activities, basing on different activity/building relations;

- the verification of the categories of relations, namely the verification of the consistency of the categories with the development of the projects, in accordance with the review and the interviews (as presented in Section $5)$.

In particular, the categorisation was based on three typologies of activity/ building relations:

34. Ibid. 
- recognition: the activity consisted in -or contributed to- the recognition of the value of the vacant building;

- appropriation: the activity consisted in -or contributed to- the appropriation of the vacant building;

- design: the activity consisted in -or contributed to- the design of the vacant building regarding its physical shape or the functions and activities hosted.

- none: the activity had no relation with the vacant building.

Baing on these four categories, which will be more extensively described in this section, the second part of the research theorised the SteRVs, recognizing them not only as categories of relations but as necessary 'steps'.

Differently from Sheffler's work, ${ }^{35}$ that individuated six operative phases in order to achieve a successful strategy of reuse, the ones described in this article are more generally valid. On the one hand, the three steps theorized have not operative purpose, i.e. they are not a directly useful tool, on the other, they offer a theoretical framework adaptable to a variety of situations, allowing the comparisons between different projects. This research in fact is a part of a more comprehensive study on bottom-up urban regeneration. Once individuated that the vacant buildings are an asset, and the macro phases through which they are embedded in regeneration strategies, the analysis and comparisons would be possible.

As anticipated, the phases individuated are three. They are called steps for regeneration through the reuse of vacant buildings (SteRVs).

- Recognition. It is the first phase, in which an actor, public or private, individuates the presence of a vacant building. The building can be 'easily found' because its location is in a traversed street, or be more 'hidden and less open to the public look. ${ }^{36}$ This first phase overcomes one of the issues faced in the reuse of vacant buildings, namely the fact that 'the opportunities are frequently not identified and often hindered or delayed by poor information. ${ }^{37}$ The 'recognition' is something similar to the 'discovery', intended as the action to 'find a space in order to put it to use', recognizing 'not just the space but a new purpose for it," 38 shifting perception. ${ }^{39}$ The spaces are 'found' through the 'recognition', in the sense that the actors identify a place where to develop functions that 'were not originally designed to serve. ${ }^{40}$ Moreover, 'recognition' not only involves the acknowledgement of the existence and the possibilities offered by a

35. Ibid.

36. K. A. Franck and Q. Stevens (eds.) Loose Space: Possibility and Diversity in Urban Life (London; New York: Routledge, 2006), 231.

37. Myers and Wyatt, "Rethinking Urban Capacity," 2004.

38. Franck and Stevens, Loose Space: Possibility and Diversity in Urban Life, 2006, 30.

39. Leonard and Mallach, Restoring Properties, Rebuilding Communities. Trasforming Vacant Properties in Today's America, 2010.

40. L. G. Rivlin, "Found Spaces," in Loose Space: Possibility and Diversity in Urban Life, 3853 (ed.) K. A. Franck and Q. Stevens. London; New York: Routledge, 2006, 39. 
space, but also to recognize the complexity of values related to a specific place, which can involve economic, social, historical, aesthetical or symbolic values.

- Appropriation. In the 'appropriation' phase an actor, be it public or private, appropriates the space, in order to reuse it and to put in place a project. Jiménez-Domínguez refers to appropriation as a 'collective activity', related to 'communication and social relatedness in urban space ... urban culture and living memory', 'based on identification. ${ }^{41}$ However, also a building, that is a closed space with usually well-defined thresholds, can be appropriated. A vacant building, that lost the functions originally assigned, have many similarities to the 'loose space' conceptualized by Franck and Stevenson, ${ }^{42}$ such as to offer a myriad of possibilities, to 'frame opportunities for expression and for social engagement' and the 'absence or abeyance of the determinacy. ${ }^{43}$ As the 'loose space', a vacant building needs to be appropriated in an intentional way, often more strategically than a generic activity 'part of the everyday life. ${ }^{, 44}$ Regarding a vacant building, which can have a private owner and be closed to public, appropriation passes through different activities that can involve also the legal and economic aspects, for instance the purchase or the rent, beyond the physical appropriation through spatial practices ${ }^{45}$. This phase can be radically different if the actor that appropriates the space is a single person, that can for instance purchase an estate, a grassroot organization, that can set up squatting strategies, ${ }^{46}$ or a public administration, that may use agreements or expropriations. ${ }^{47}$ As defined by Schneider and Till in the project 'Spatial Agency', appropriation 'can include the taking of another's property for one's own purposes (either legally or illegally, short-term or long-term), or through highlighting abandoned or unoccupied space. ${ }^{48}$

- Design. It is the phase through which the actors involve the building and its specificity in a project of reuse, reactivating it. The 'design' phase is the one where the activities inside the building, or in the external spaces, are linked to a more comprehensive urban strategy that considers also the surrounding urban fabric. This can be explicit, in the intention of the promoter, but also implicit, and become a spontaneous regeneration project. The 'design' phase, in the bottom-up projects, often involve not

41. B. Jiménez-Domínguez, "Urban Appropriation and Loose Spaces in the Guadalajara Cityscape," in Loose Space: Possibility and Diversity in Urban Life, 96-112 (eds.) K. A. Franck and Q. Stevens. London; New York: Routledge, 2006, 99.

42. Franck and Stevens, Loose Space: Possibility and Diversity in Urban Life, 2006.

43. Ibid, 9, 17.

44. Ibid, 29.

45. R. Boer, M. Otero Verzier and K. Truijen, Architecture of Appropriation. On Squatting as Spatial Practice (Rotterdam: Het Nieuwe Instituut, 2019).

46. Ibid.

47. J. Badcock, Barcelona Orders First Expropriation of "Empty" Flat Owned by a Bank (The Telegraph, 2019).

48. Spatial Agency: How? Appropriation. Retrieved from: https://www.spatialagency.net/da tabase/how/appropriation/. [Accessed 8 November 2019]. 
only professionals but also citizens. ${ }^{49}$ As conceptualized by Manzini, ${ }^{50}$ and demonstrated in a previous work referring to the bottom-up urban regeneration projects, these experiences are made both by 'diffuse design' figures, the citizens, and 'expert designers', the professionals. From the collaboration of this variety of actors born the 'bottom-up' urban regeneration projects, whose design involve the strategic use of the buildings as assets. It is a spontaneous co-design process, where the affordability of the vacant buildings becomes strategic to the sustainability of the initiative.

The following sections will demonstrate how the so-defined three phases are consistent with the real practice, and how it is possible to recognize them in two projects that are considered exemplary European cases of bottom-up urban regeneration. In particular, the article will demonstrate that it is possible to interpret the process of strategically embedding a vacant building into a bottom-up UR project through the mentioned three different steps.

\section{The Case Studies}

The informal urban practices in literature have been traditionally categorized basing on the duration, distinguishing between permanent and temporary projects. The research 'Urban Catalyst, ${ }^{51}$ used 'temporary' to define the projects 'if those initiating it and the other actors involved expected it to be of limited duration', however, they also admitted that "uses can lose their classification as "temporary" as soon as their status changes and they consolidate into established use. ${ }^{52}$ The definition of 'temporary' appears a loose concept, not defining the peculiar characteristic of the urban practices. Paraphrasing the words of Cirille Hanappe, ${ }^{53}$ perhaps would be useful to admit that there is not 'temporary reuse', but only the 'reuse. ${ }^{54}$ In the framework of this specific research, it seems not useful to make the distinction between projects born to be temporary or more permanent ones. If the concept of 'temporariness' still has its validity in successfully grasping a certain grade of informality and improvisation in these kinds of urban practices, however, the duration appears not to be the main characteristic. Basing on these 2014

49. Tonkiss, "From Austerity to Audacity: Make-Shift Urbanism and the Post-Crisis City,"

50. E. Manzini, Design, when Everybody Designs: An Introduction to Design for Social Innovation (Cambridge, Massachusetts: The MIT Press, 2015).

51. Oswalt, Overmeyer, and Misselwitz, Urban Catalyst: The Power of Temporary Use, 2013.

52. Oswalt, Misselwitz and Overmeyer, "Patterns of the Unplanned," 2006, 275.

53. 'Il n'y a pas d'habitat temporaire. Il n'y a que de l'habitat. Il y a des chemins de vie, qui font que l'on passe d'un habitat à l'autre. Et il n'y a pas un lieu où l'on dort qui n'a la même attention qu'un palais, car ce quelqu'un y habite, pour plus longtemps qu'il n'aurait pensé'

54. C. Hanappe, Il n'y a Pas d'Habitat Temporaire. Il n'y a Que de l'Habitat (Habiter Le Temporaire, Cité de l'Architecture et du Patrimoine, 2017), 79. 
considerations, the article considers 'bottom-up' urban projects, without distinguishing in permanent or temporary, the ones that:

- $\quad$ involve the return of benefits to the local community; ${ }^{55}$

- do not only deal with physical improvements, but also social relations, ownership models, resource funding strategies; ${ }^{56}$

- $\quad$ are based on the reuse of vacant buildings, as a necessary precondition for these initiatives to born and develop.

All around Europe there are cases of reuse of abandoned building by communities of citizens: Manifatture Knos in Lecce (Italy), Farm Cultural Park in Favara (Italy), NDSM wharf in Amsterdam, ${ }^{57}$ Ex Rotaprint in Berlin, ${ }^{58}$ Zinneke and Recyclart in Brussels, are only some examples of a huge tendency in Europe that finds in abandoned buildings the occasion for innovative projects. As mentioned above, some of these bottom-up projects are linked to the concept of UR. In the following sections, two renowned European cases are presented, analysing their development using the SteRVs as a conceptual framework. The two cases selected are both considered exemplary and recognized best-practices of bottom-up urban regeneration in Europe.

Farm Cultural Park is one of the few bottom-up projects in Europe whose declared main goal is urban regeneration. For this reason, it is considered a world best-practice, as demonstrated by the countless invitations received by Andrea Bartoli and Florinda Saieva as guest lecturers, jury members and testimonials. Farm project has been presented worldwide, to mention:

- Architecture Biennale of Venice (2012 and 2016);

- Dublin Platform on 'Heritage and Social Innovation' 2018 (European Commission);

- The Future of Historic Villages and Towns 2019, Meishan, China (UNESCO);

- ILUCIDARE Playground 2019, Brussels (KU Leuven, KEA and others Horizon 2020 project);

- $10^{\text {th }}$ Urban Forum 2020, Abu Dhabi (UN Habitat).

NDSM is considered a world best-practice too, and after two decades it still arises interests among academics, as demonstrated by the invitations received by one of the more engaged promoters, Eva de Klerk, who considers herself as a

55. Rabbiosi, "Urban Regeneration "from the Bottom up": Critique or Co-Optation? Notes from Milan, Italy,” 2016.

56. Tonkiss, "From Austerity to Audacity: Make-Shift Urbanism and the Post-Crisis City," 2014.

57. E. De Klerk, C. Feldbrugge and J. Zonneveld, Make your City: The City as a Shell: NDSM Shipyard Amsterdam (Trancity-Valiz, 2018).

58. F. Ferguson, F. and Urban Drift Projects (eds.) Make_shift City: Renegotiating the Urban Commons; Die Neuverhandlung Des Urbanen (Berlin: Jovis, 2014). 
'bottom-up city developer. ${ }^{59}$ Eva has been invited, to explain NDSM project, in several events around the globe:

- The city as a shell, a manual for designing the city, 2020, Ghent (Ku Leuven);

- The design after, 2019, Bogota, Colombia (Universidad de los Andes);

- Perspectivas y oportunidades de la ciudad construida, 2013, Valencia (Aula Ciutat, Universidad Internacional Menéndez Pelayo);

- Yokahama Creative City 2008, Japan (Yokohama city council);

- Workshop for the redevelopment of the Berlin Tempelhof, 2007, Berlin (Municipality of Berlin).

\section{FARM Cultural Park}

Favara is a town in the South-East of Sicily, in Italy. In 2010, after the tragic death of two children due to the collapse of a historic building in the city centre, ${ }^{60}$ the municipal administration decided to earmark for demolition all buildings that were not considered safe. ${ }^{61}$

In the same year, Andrea Bartoli and Florinda Saieva, a married couple, decided to accelerate the development of a project they had in mind. They were thinking about a project to change the conditions of the historic centre of Favara, that was semi-abandoned, with a high rate of unemployment and many buildings built without permits. ${ }^{62}$ The town did not have any strong touristic or industrial destination, and the 2008 economic crisis was a disaster for the several construction companies of this zone (Figure 1). The Bartolis made the initial economical investment to purchase some buildings in the city centre, called Sette Cortili (Seven Courtyards) with the intention to build a new independent cultural centre. The design by architect Liotta, Castelli and others led to the opening of new spaces, that are now linked with each other, and the general refurbishment and renewal. ${ }^{63}$ Today thanks to the urban regeneration operated by Farm Cultural Park, the economy of the city has been reactivated, becoming the second touristic destination of Agrigento Province, attracting many people, and thus producing the necessity of open structures to welcome them such as B\&Bs, hotels, restaurants, cafes. ${ }^{64}$

59. About Eva | Eva De Klerk, Retrieved from: http://www.evadeklerk.com/en/bio/. [Accessed 30 March 2020].

60. Corriere della Sera Redazione Online, Crolla Palazzina a Favara Morte Due Bambine, Salvo Il Fratello (Corriere Della Sera. Corriere.it, 2010).

61. S. Consiglio and A. Riitano, Sud Innovation: Patrimonio Culturale, Innovazione Sociale e Nuova Cittadinanza (Milano: F. Angeli, 2015).

62. G. Faraci, "Farm Cultural Park: An Experience of Social Innovation in the Recovery of the Historical Centre of Favara," Procedia Environmental Sciences 37 (2017): 676-688. 2016).

63. M. Di Carlentini and S.-J. Liotta, Farm Cultural Park (Favara, Italia) (08_Planur-e,

64. J. A. Liotta di Salvator, Sfascio. Miracolo. Domani. Su Farm Cultural Park e il suo Valore. Archivio della Generatività Sociale. 


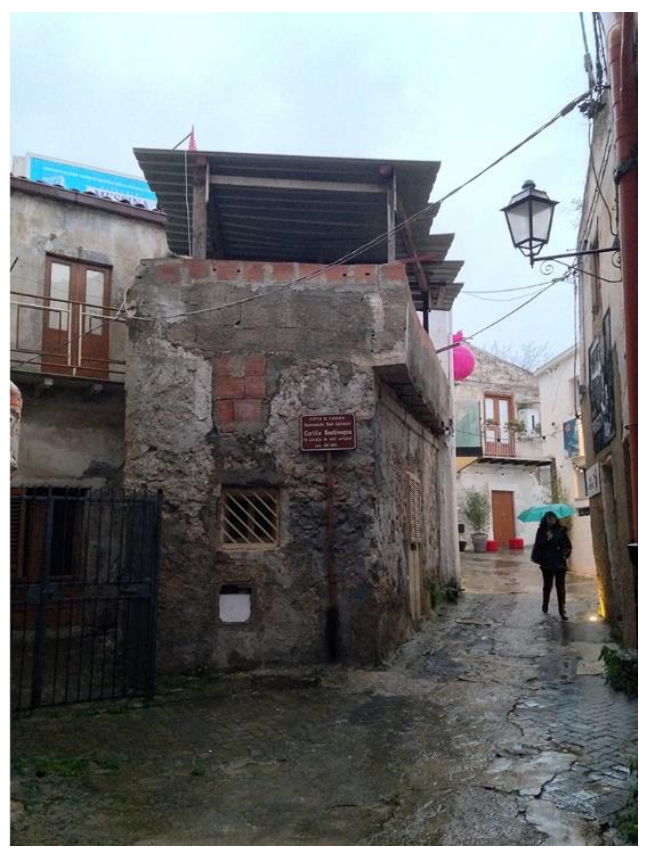

Figure 1. Cortile Bentivegna before Farm's Project Source: Di Carlentini and Liotta. ${ }^{65}$

Recognition. The Bartolis, in a moment of their life, decided to go back to Sicily. They decided to live in Favara after having lived in Paris for a period, to reconnect to their native place and their families. ${ }^{66}$ They knew the town very well, mostly Florinda that was born in Favara, and they were aware of the conditions of the architectural heritage. The buildings purchased constituted an occasion for the couple. Sette Cortili was a semi-abandoned area, unsafe and in poor structural conditions. ${ }^{67}$ However, according to Andrea Bartoli, ${ }^{68}$ the purchased happened almost by chance, as he and Florinda were considering different buildings in the city centre. However, the recognition phase passes through the acknowledgement of the value of the historic centre, as a part of the city that deserves to be regenerated, in opposition to the 1980s external real estate development of Favara in large part abusive. Furthermore, from other interviews carried out in Favara, it was made clear that the success of the FARM is also due to chosen area, called Sette Cortili, that was the symbol of the historic town (Figure 2).

Appropriation. The 'appropriation' phase passed through the purchase, at a very low price, of the vacant and neglected buildings. This was not an exceptional possibility in the city centre, as demonstrated by the interviews to some local experts. ${ }^{69}$ A lot of buildings in the city centre were in fact sold at a very low price, others were earmarked for demolition. The Bartolis' choice to purchase them in the historic centre demonstrated the existence of a possibility for the regeneration.

65. Di Carlentini and Liotta, Farm Cultural Park (Favara, Italia,) 2016.

66. A. Bartoli, Cities Change because People Make them Changing (TEDxTalks TEDxLakeComo, 2017).

67. Di Carlentini and Liotta, Farm Cultural Park (Favara, Italia,) 2016.

68. Personal Interview.

69. C. Cuschera and A. Cuschera, Personal Interview, 2019. 
Andrea Bartoli, notary by profession, purchased the buildings in the historic centre in the more classical way. The appropriation was an economic and legal transaction that allowed the Bartolis to become owners of the former vacant buildings. But after that, as pointed out by Faraci, ${ }^{70}$ they also developed a 'process of recovery, re-appropriation' that provided 'new meaning to the area by involving artists and designers'. The very poor conditions of the buildings were not only the issues tackled by the Bartolis but were also the premise that allowed the purchase at a very low price, consenting de facto the project to develop.

Design. The 'design' phase included physical and non-physical interventions. The renewal of the buildings involved the restoration of walls, windows and doors, the refurbishment of the interiors and the connection of the different spaces. As demonstrated in a forthcoming article, the design phase included the setting up of social cooperatives and art and culture events and expositions. The design phase heavily continued also after the purchase of the first buildings. It involved the collaboration of the Bartolis with the professionals, like the architects Castelli and Liotta, but also the graphic designers, the video makers etc. According to Andrea Bartoli, the design of the initiative is very demanding and absorbing, even if the results seem so immediate. ${ }^{71}$

Farm Cultural Park reactivated some vacant buildings in the city centre of Favara, hosting the new functions, succeeding in animating the whole city centre. Farm Cultural Park is a clear example of how, through the mentioned three steps, vacant buildings can be the trigger for the regeneration of an urban area, in this case of an historic neglected centre.

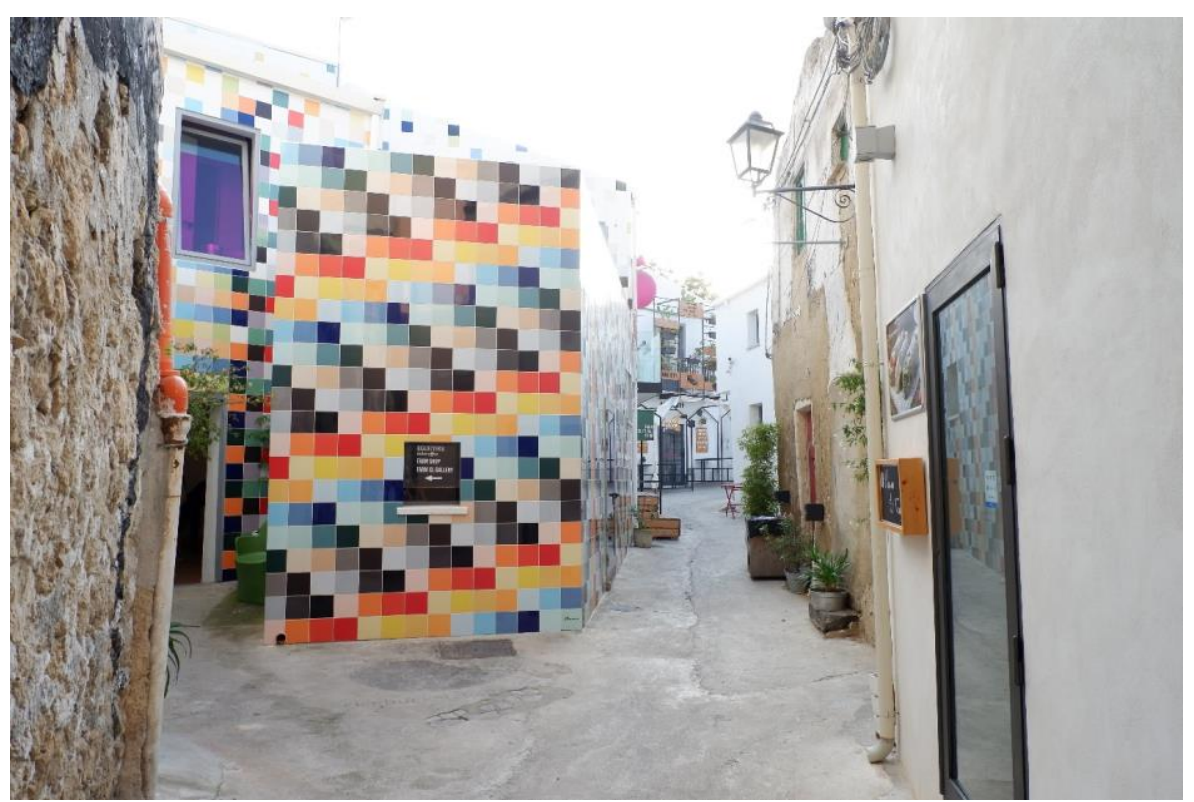

Figure 2. Farm Cultural Park, Main Entrance (Sette Cortili)

Source: Author (2019).

70. Faraci, "Farm Cultural Park: An Experience of Social Innovation in the Recovery of the Historical Centre of Favara," 2017, 677.

71. Andrea Bartoli, talking about the initiative 'Countless Cities', said that it has taken some months to develop the concept, while once realized it seems so immediate. 


\section{NDSM Wharf}

The wharf of the Netherland Dock and Shipbuilding Company is situated in a neighbourhood with an industrial past in the north bank of the IJ river of Amsterdam (Figure 3). The area is abandoned from the 1980. In this context, an abandoned industrial building has become not only the bigger sanctuary of Europe, but also has succeeded in changing the perception of the whole area. In 2000 the creative group Kinetisch Noord, made up of artists, craftsmen, skaters and no-profit organizations, started the process of regeneration of a building in this area, the old shipbuilding warehouse, in order to create affordable rent studios, a theatre, dance spaces, a skate park and either a school. ${ }^{72}$ They achieved also the reuse of internal spaces as ateliers, using adaptable architectural structures designed by Dynamo architects. ${ }^{73}$ They could achieve this result through the cooperation with local governments, building authorities and professionals, becoming one of the bigger examples in Europe of regeneration from the bottom up.

However, also the public administration played a role in the development of the wharf. In 1999 the Amsterdam Nord municipality organised a competition for assigning the building to an association with a project for the temporary reuse of the NDSM shipyard. ${ }^{74}$ The role of public administration is however restricted to activities of 'supervising and supporting the process. ${ }^{75}$

From this point, the history of the NDSM regeneration is the one of a bottomup regeneration: the Kinetisch Noord raised money in order to submit an entry in the competition, raised a consistent network of people around the initiative and succeed in winning the bid. ${ }^{76}$ In the years that followed the community of the NDSM organised in 4 entities: an umbrella organization, the tenants, an external board, and a foundation. ${ }^{77}$

Recognition. The North bank of the IJ was almost not considered as a part of the city of Amsterdam. As stated by Chris Keulemans, artistic director of the Tolhuistuin, "Noord used to be to Amsterdam what Australia used to be to England', a place where to send 'criminals, their alcoholics, their homeless, their general outcasts. ${ }^{78}$ It is clear that the recognition of the value of this area, similarly to the FARM case, needed to pass through the acknowledgement of any sort of value. The recognition, in effect, happened years before the proper reuse by

72. De Klerk, Feldbrugge and Zonneveld, Make your City: The City as a Shell: NDSM Shipyard Amsterdam, 2018. 2008).

73. D. Bakker, Architectuur in Nederland: Jaarboek 2007/08 (Rotterdam: NAi Publishers,

74. P. Bishop, "From the Subversive to the Serious: Temporary Urbanism as a Positive Force," Architectural Design 85, no. 3 (2015): 136-141.

75. X. Gainza, "Industrial Spaces for Grassroots Creative Production: Spatial, Social and Planning Facets,” European Planning Studies 26, no. 4 (2018): 807.

76. De Klerk, Feldbrugge and Zonneveld, Make your City: The City as a Shell: NDSM Shipyard Amsterdam, 2018.

77. Ibid.

78. J. Weickgenant, “The Noord District's Hip Rebirth. How One Amsterdam Neighborhood Became Trendy, Drawing Artists, Musicians and Eateries,” Wall Street Journal, Europe (2011), 1. 
Kinetisch Noord, and it is evident from the activities of other actors of Amsterdam's vibrant cultural scene. As reported by Eva de Klerk, ${ }^{79}$ the NDSM shipyard was already used, previously, as a stage by Dogtroep, 'an international site-specific theatre company, creating shows at extreme locations. ${ }^{80}$ As reported by Anna Threes, artistic director of Doegtrop from 1990 to 1999, 'in August 1994 Dogtroep played Noordwesterwals for a month, on a slipway of the former NDSM shipyard in Amsterdam-Noord. ${ }^{, 81}$ However, there are 'still very few people that recognize the potential of the transformation of the shipyard buildings in 1998.,82 Eva de Klerk, as a promotor of Kinetisch Noord, has seen potentials in this part of the city, and Jolien van der Maden, an entrepreneur of the food sector, and Maik ter Veerm, organizer of art and technology festival Robodock, have done the same. Also, a number of theatre companies were urgently searching for available spaces. The NDSM shipyard represented a spatial and aesthetic asset for these actors. In fact, the character of the industrial site was considered 'appealing', even thought that part of the city was not "very popular at the time. ${ }^{, 83}$ However, it is possible to say that also the municipality of Amsterdam has acknowledged the value of the building. In fact, in a time when 'it is still unclear what the future of the NDSM shipyard will be ${ }^{84}$ the District Noord decides to organize a public competition for the reuse of the shipyard. This demonstrates the intention not to demolish the building but instead to preserve its integrity giving new functions.

Appropriation. The appropriation of the NDSM wharf is a complex phase. From the legal point of view, it passed through the winning of a public competition organized by District Noord of Amsterdam (Figure 4). This led to the legal appropriation of the space by the grassroots organization Kinetisch Noord, that winning the competition concluded the first agreement with the municipality of Amsterdam Noord for a five years use, then extended. ${ }^{85}$ The appropriation through the reuse of the space, however, happened even before. In the years after the Dogtroep performance, in fact, the NDSM wharf was 'one of the options people can move to when the evictions on the south bank of the IJ start to become concrete. ${ }^{86}$ The port buildings are appropriated by people coming from other squat experiences, such as ADM site and Plantage Doklaan. ${ }^{87}$ It is evident, form the description of this variety of experiences that the appropriation by different actors, through spatial practices, happened before the legal appropriation by

79. De Klerk, Feldbrugge and Zonneveld, Make your City: The City as a Shell: NDSM Shipyard Amsterdam, 2018.

80. A. Threes, Dogtroep - Threes Anna. Threesanna.Com (blog).

81. 'In Augustus 1994 speelde Dogtroep een maand lang Noordwesterwals, op een scheepshelling van de voormalige NDSM-scheepswerf in Amsterdam-Noord.'; Ibid.

82. De Klerk, Feldbrugge and Zonneveld, Make your City: The City as a Shell: NDSM Shipyard Amsterdam, 2018, 69.

83. Ibid.

84. Ibid, 73.

85. De Klerk, Feldbrugge and Zonneveld, Make your City: The City as a Shell: NDSM Shipyard Amsterdam, 2018.

86. Ibid, 73.

87. De Klerk, Feldbrugge and Zonneveld, Make your City: The City as a Shell: NDSM Shipyard Amsterdam, 2018. 
Kinetisch Noord. However, when the building is assigned to Kinetisch Noord, the appropriation becomes more structured and less informal and guided by the winning bid for the reuse.

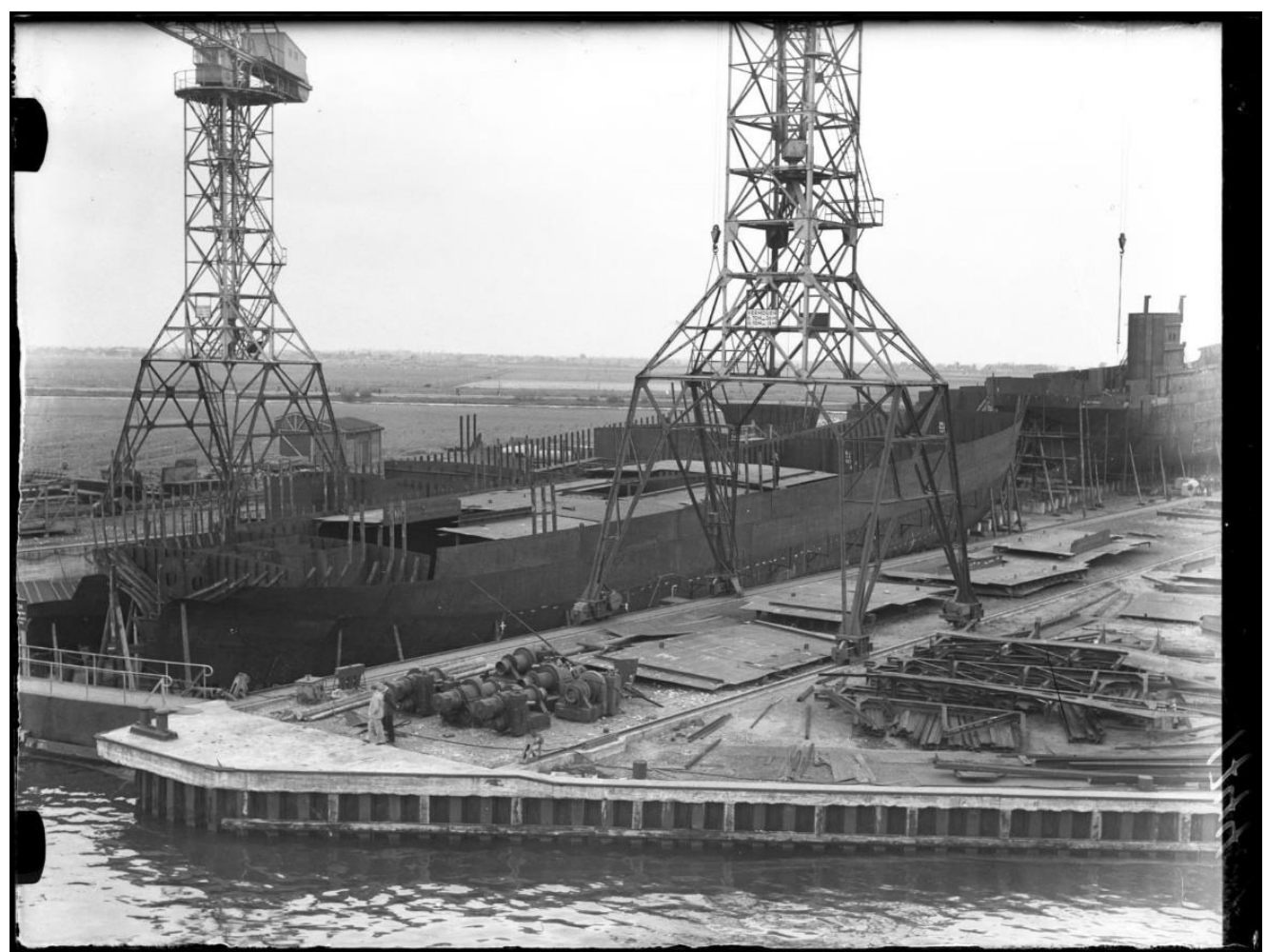

Figure 3. Ships under Construction at the NDSM Shipyard, May 16, 1947. Photo Ben van Meerendonk / AHF, IISH Collection, Amsterdam. Source: IISG, 05-16-1947_01744 NDSM. ${ }^{88}$

Design. The design phase started before the legal appropriation, with the preparation of the dossier to submit to the public administration. Differently from other totally private-led initiatives, the design phase has been very demanding also in the preliminary phase, involving a lot of people and professionals and requiring an initial investment. ${ }^{89}$ The design phase appears to be typical only of the Kinetisch Noord activities, and not of other actors that appropriated the building before. In fact, it seems that the previous appropriations of the areas were characterized by informality and the lack of legal basis, and did not allow to make mid-term programs for the area. The public bid is a shifting point in the approach for the area. In fact, from this moment, it is possible to individuate an actor, the grassroots organization, but also a design plan, that foresight a future for the area regarding the activities and the financial plan. The design phase appears to be an interdisciplinary work, and as demonstrated for the FARM's case, not only involved professionals with different expertise but also citizens. The design phase included a 'crowdfunding avant la lettre' campaign in order to raise the money

88. IISG, 05-16-1947_01744 NDSM.

89. Ibid. 
necessary to design and print the competition proposal..$^{90}$ The design phase for the NDSM wharf was in large part influenced by the need to build a dossier to enter the competition.

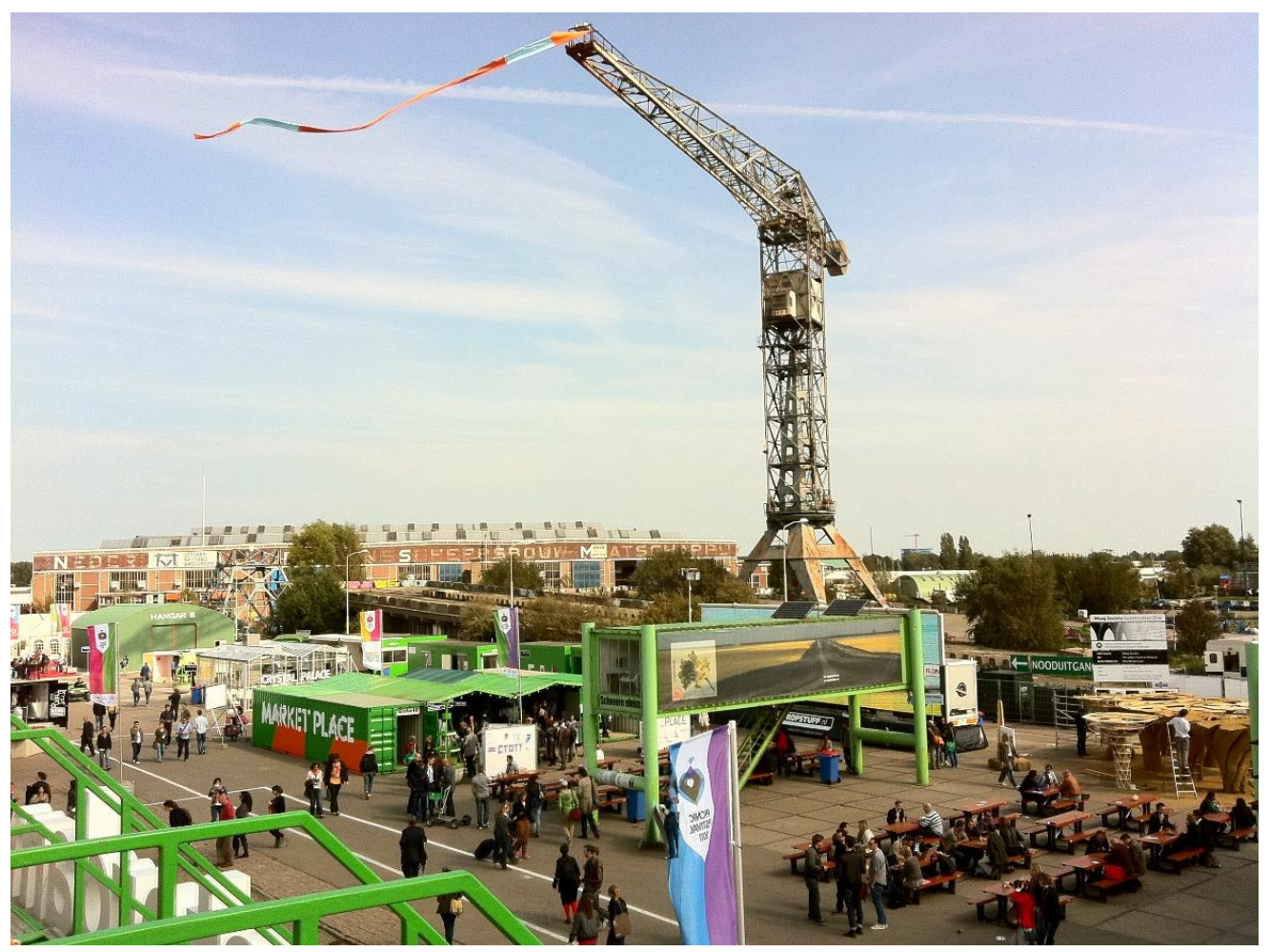

Figure 4. Old Crane at the PICNIC11 Site in Amsterdam (NDSM Wharf) Source: Nash, NDSM Wharf Crane Amsterdam - 14. ${ }^{91}$

\section{Conclusions}

The SteRVs constitute a theoretical instrument to analyse and understand how the vacant buildings are embedded in an urban regeneration strategy developed from the bottom up. It is possible to recognize the SteRVs also as more universal categories, which can be applied also to other processes of reuse. However, this article is limited to the development of a conceptual framework that will be directly used in research conducted on bottom-up urban regeneration, and the case studies refer to this phenomenon. This does not limit the applicability, under further study, to a wider range of cases.

Regarding the usefulness of such a theoretical concept, the SteRVs will be fundamental in:

- analysing, as done in this article, how these complex projects develop, also admitting comparisons;

90. Ibid, 77.

${ }^{91}$ A. Nash, NDSM Wharf Crane Amsterdam - 14. 
- understating how the vacant buildings have been chosen and used in the urban regeneration strategies, allowing speculations on the reasons that allowed or not the success of the initiatives.

Moreover, through the analysis of the two case studies, this article demonstrates how the abandoned buildings can become part of these strategies, independently from the actors and the path followed. The recognition of the presence of an abandoned building that can be reused for different functions, the appropriation through formal or informal activities and the design of a new function to reactivate the building in an urban strategy appear to be three indispensable phases. For this reason, it is possible to state that the SteRVs constitute a useful framework in order to better understand bottom-up urban regeneration projects.

\section{Bibliography}

About Eva | Eva De Klerk. Retrieved from: http://www.evadeklerk.com/en/bio/. [Accessed 30 March 2020].

Acierno, A. "Integrated Urban Development and Culture-Led Regeneration in the EU." Territory of Research on Settlements and Environment. International Journal of Urban Planning 10, no. 1 (2017): 7-14.

Alker, S., V. Joy, P. Roberts and N. Smith. "The Definition of Brownfield." Journal of Environmental Planning and Management 43, no. 1 (2000): 49-69.

Attoe, W. and D. Logan. American Urban Architecture: Catalysts in the Design of Cities. Berkeley: University of California Press, 1989.

Badcock, J. Barcelona Orders First Expropriation of "Empty" Flat Owned by a Bank. The Telegraph, 2019. Retrieved from: https://bit.ly/2WNbD1u.

Bakker, D. Architectuur in Nederland: Jaarboek 2007/08. [Architecture in the Netherlands: Yearbook 2007/08.] Rotterdam: NAi Publishers, 2008.

Bartoli, A. Cities Change because People Make them Changing. TEDxTalks TEDxLake Como, 2017.

Bishop, P. "From the Subversive to the Serious: Temporary Urbanism as a Positive Force." Architectural Design 85, no. 3 (2015): 136-141.

Boer, R., M. Otero Verzier and K. Truijen. Architecture of Appropriation. On Squatting as Spatial Practice. Rotterdam: Het Nieuwe Instituut, 2019.

Consiglio, S. and A. Riitano. Sud Innovation: Patrimonio Culturale, Innovazione Sociale e Nuova Cittadinanza. [Innovation: Cultural Heritage, Social Innovation and New Citizenship.] Milano: F. Angeli, 2015.

Corriere della Sera Redazione Online. Crolla Palazzina a Favara Morte Due Bambine, Salvo Il Fratello. [Apartment House Collapses in Favara Death of Two Girls, except for the Brother.] Corriere Della Sera. Corriere.it, 2010. Retrieved from: https://bit.ly/ 32VYgjD.

Cuschera, C. and A. Cuschera. Personal Interview. 23 October 2019.

De Klerk, E., C. Feldbrugge and J. Zonneveld. Make your City: The City as a Shell: NDSM Shipyard Amsterdam. Trancity-Valiz, 2018.

Di Carlentini, M. and S.-J. Liotta. Farm Cultural Park (Favara, Italia). 08_Planur-e, 2016. ISSN 2340-8235. 
Fanovard, J. Convention d'occupation précaire et temporaire à Bruxelles. Une solution à la crise du logement? [Precarious and Temporary Occupation Agreement in Brussels. A Solution to the Housing Crisis?] Bruxelles: CPCP, 2017.

Faraci, G. "Farm Cultural Park: An Experience of Social Innovation in the Recovery of the Historical Centre of Favara." Procedia Environmental Sciences 37 (2017): 676688.

Ferguson, F. and Urban Drift Projects (eds.) Make_shift City: Renegotiating the Urban Commons; Die Neuverhandlung Des Urbanen. Berlin: Jovis, 2014.

Franck, K. A. and Q. Stevens (eds.) Loose Space: Possibility and Diversity in Urban Life. London; New York: Routledge, 2006.

Franklin, A. "Journeys to the Guggenheim Museum Bilbao: Towards a Revised Bilbao Effect." Annals of Tourism Research 59 (2016): 79-92.

Gainza, X. "Industrial Spaces for Grassroots Creative Production: Spatial, Social and Planning Facets." European Planning Studies 26, no. 4 (2018): 792-811.

Hanappe, C. Il n'y a Pas d'Habitat Temporaire. Il n'y a Que de l'Habitat. [There is No Temporary Habitat. There is only Habitat.] Habiter Le Temporaire, Cité de l'Architecture et du Patrimoine, 2017, 79.

IISG. 05-16-1947_01744 NDSM. 16 May 1947. Photo. https://www.flickr.com/photos/ iisg/11465512053/.

Jiménez-Domínguez, B. "Urban Appropriation and Loose Spaces in the Guadalajara Cityscape." In Loose Space: Possibility and Diversity in Urban Life, 96-112. Edited by K. A. Franck and Q. Stevens. London; New York: Routledge, 2006.

Leonard, J. R. and A. Mallach. Restoring Properties, Rebuilding Communities. Trasforming Vacant Properties in Today's America. Center for Community Progress, 2010.

Liotta di Salvator J. A. Sfascio. Miracolo. Domani. Su Farm Cultural Park e il suo Valore. [Shambles. Miracle. Tomorrow. About Farm Cultural Park and its Value.] Archivio della Generatività Sociale. Retrieved from: http://www.generativita.it/it/analysis/sfa scio-miracolo-domani-su-farm-cultural-park-e-il-suo-valore/8/. [Accessed 9 July 2019].

Mallach, A., A. Haase and K. Hattori. "The Shrinking City in Comparative Perspective: Contrasting Dynamics and Responses to Urban Shrinkage." Cities 69 (2017): 102108.

Manganelli, B. Real Estate Investing. Cham: Springer International Publishing, 2015.

Manzini, E. Design, when Everybody Designs: An Introduction to Design for Social Innovation. Cambridge, Massachusetts: The MIT Press, 2015.

Marcuse, P. "Gentrification, Abandonment, and Displacement: Connections, Causes, and Policy Responses in New York City." Washington University Journal of Urban and Contemporary Law 28 (1985): 195-240.

Metris Arts Consulting, and Center for Community Progress. Creative Placemaking on Vacant Properties: Lessons Learned from Four Cities. Center for Community Progress, 2018. Retrieved from: https://www.communityprogress.net/download-crea tive-placemaking-on-vacant-properties-pages-545.php.

Myers, D. and P. Wyatt. "Rethinking Urban Capacity: Identifying and Appraising Vacant Buildings." Building Research \& Information 32, no. 4 (2004): 285-292.

Nash, A. NDSM Wharf Crane Amsterdam - 14. 16 September 2011. Photo. https://www. flickr.com/photos/andynash/8753636776/.

Oswalt, P., P. Misselwitz and K. Overmeyer. "Patterns of the Unplanned." In Loose Space: Possibility and Diversity in Urban Life, 271-288. Edited by K. A. Franck and Q. Stevens. London; New York: Routledge, 2006. 
Oswalt, P., K. Overmeyer and P. Misselwitz (eds.) Urban Catalyst: The Power of Temporary Use. Berlin: DOM Publishers, 2013.

Porcelloni, L., L. Cusseau, S. Amini and F. Mazzelli. "Abbandono Di Aree Rurali e Reti Innovative Di Rigenerazione: Una Proposta Di Nuovi Modelli Dell'Abitare Attraverso Una Mappatura Condivisa." [Abandonment of Rural Areas and Innovative Regeneration Networks: A Proposal for New Models of Living through Shared Mapping.] In Territori Spezzati. Spopolamento e Abbandono Nelle Aree Interne Dell'Italia Contemporanea, 149-154. Edited by G. Macchi Jánica and A. Palumbo. Roma, CISGE - Centro Italiano per gli Studi Storico-Geografici, 2019.

Rabbiosi, C. "Urban Regeneration "from the Bottom up": Critique or Co-Optation? Notes from Milan, Italy." City 20, no. 6 (2016): 832-844.

Rivlin, L. G. "Found Spaces." In Loose Space: Possibility and Diversity in Urban Life, 3853. Edited by K. A. Franck and Q. Stevens. London; New York: Routledge, 2006.

Roberts, P. W. "The Evolution, Definition and Purpose of Urban Regeneration." In Urban Regeneration, 9-43. Edited by P. W. Roberts, H. Sykes and R. Granger. $2^{\text {nd }}$ Edition. Los Angeles: Sage, 2017.

Sayin, B. Personal Interview. 6 November 2019.

Scheffler, N. Waking up the Sleeping Giants. An Urban Guidebook for the Reactivation and Reuse of Larger Vacant Buildings. URBACT, 2018. Retrieved from: https://urbact.eu/sites/default/files/media/2nd_chance_guidebook.pdf.

Spatial Agency: How? Appropriation. Retrieved from: https://www.spatialagency.net/da tabase/how/appropriation/. [Accessed 8 November 2019].

Spelman, W. "Abandoned Buildings: Magnets for Crime?" Journal of Criminal Justice 21, no. 5 (1993): 481-495.

Squizzato, A. "Understanding and Evaluating Bottom-up Urban Regeneration." In Urbanism Research across the World: Proceedings of the PHD Seminar, 34-39. Edited by K. Shannon and M. Quang Nguyen. Leuven: KU Leuven Department of Architecture, 2019.

"Urban Regeneration: Understanding and Evaluating Bottom-up Projects." Urbanities 9, no. 2 (2019): 19-35.

Threes, A. Dogtroep - Threes Anna. Threesanna.Com (blog). Retrieved from: http:// www.threesanna.com/dogtroep/. [Accessed 11 November 2019].

Tonkiss, F. "From Austerity to Audacity: Make-Shift Urbanism and the Post-Crisis City." In Make_shift City: Renegotiating the Urban Commons; Die Neuverhandlung Des Urbanen, 165-167. Edited by F. Ferguson and Urban Drift Projects. Berlin: Jovis, 2014.

Trans Europe Halles. "How to Become a Member.” Trans Europe Halles (2019). Retrieved from: http://teh.net/members/.

Weickgenant, J. "The Noord District's Hip Rebirth. How One Amsterdam Neighborhood Became Trendy, Drawing Artists, Musicians and Eateries." Wall Street Journal, Europe (2011).

Wilkinson, L. "Vacant Property: Strategies for Redevelopment in the Contemporary City." (2011) Retrieved from: http://hdl.handle.net/1853/40778.

Winthrop, B. and R. Herr. "Determining the Co\$t of Vacancies in Baltimore." Government Finance Review 25, no. 3 (2009): 38-42.

Yin, R. K. Case Study Research: Design and Methods. $2^{\text {nd }}$ Edition. Applied Social Research Methods Series, Volume 5. Thousand Oaks: Sage Publications, 1994. 
